\title{
Keggin Structure and Surface Acidity of 12-Phosphotungstic Acid Grafted Zr-MCM-48 Mesoporous Molecular Sieves
}

\author{
Zhiqi Wang $^{1 *}$, Juan Navarrete ${ }^{2}$ \\ ${ }^{1}$ The American School Foundation, Bondojito No. 21, Col. Las Americas, México D.F., Mexico \\ ${ }^{2}$ Dirección de Investigación y Posgrado, Instituto Mexicano del Petróleo, \\ Eje Lázaro Cárdenas Norte No. 152, México D.F., Mexico \\ Email: *wang_extreme@hotmail.com
}

Received April 1, 2012; revised May 21, 2012; accepted May 31, 2012

\begin{abstract}
A zirconium modified MCM-48 mesoporous material was synthesized by surfactant-templated method. Surface grafting Zr-MCM-48 with tungstophosphoric acid led to a great enhancement of both the number of the Brønsted acid sites and acidity strength in comparison with the bare support. At $100^{\circ} \mathrm{C}$, the $30 \mathrm{wt} \% \mathrm{H}_{3} \mathrm{PW}_{12} \mathrm{O}_{40} / \mathrm{Zr}-\mathrm{MCM}-48$ contained $174 \mu \mathrm{mol} / \mathrm{g}$ Brønsted acid sites which were 21.7 times greater than that of Zr-MCM-48. The Keggin structure of the grafted heteropolyacid was rather stable after calcination at $400^{\circ} \mathrm{C}$ for $2 \mathrm{~h}$, approximately $93.3 \%$ of Keggin structure in the dispersed heteropolyacid were remained without destruction but slightly distorted in some degree, as evidenced by FTIR characterization and ${ }^{31} \mathrm{P}$ NMR-MAS analysis. This $\mathrm{H}_{3} \mathrm{PW}_{12} \mathrm{O}_{40} / \mathrm{Zr}-\mathrm{MCM}-48$ solid with three dimensional mesoporous system, large surface area and very strong Brønsted acidity will be a promising catalyst for acid catalytic reactions.
\end{abstract}

Keywords: Zr-MCM-48; Surface Acidity; Heteropolyacid; Spectroscopic Characterization

\section{Introduction}

In the history of porous materials discovery, the synthesis of M41S mesoporous materials reported by Mobil Company in 1992 occupies an important position because they bridge microporous and macroporous materials [1]. The unique properties of these mesoporous materials like large surface area, great porosity, ordered pore system and narrow pore size distribution make them very attracttive in the fields like pharmaceutical and fine chemical industries, petrochemical and refinery, adsorption and separation processes and heterogeneous catalysis [2-6].

One member of this novel M41S family, Si based cubic type MCM-48 solid, has a structure consisting of separate three-dimensional channel systems $[7,8]$. It is recognized that MCM-48 is superior to MCM-41 which has a one-dimensional pore system in the catalytic applications because the three-dimensional interwoven channels in MCM-48 could allow reactants and products faster diffusion, and thus enhance the mass transfer kinetics and avoid pore blocking [9]. However, the pure siliceous mesoporous materials have some disadvantages like low hydrothermal stability, neutral framework and

*Corresponding author. lack of active sites in the pore wall which limit their special applications. It is impossible, for example, to directly use Si-based MCM-48 as catalyst in the reactions like alkylation and isomerization of alkanes owing to lack of Brønsted acidity; it is impossible to use it as adsorbent for wastewater treatment due to its hydrothermal instability in an aqueous solution.

The thermal and hydrothermal stability of Si-based MCM-48 could be improved by framework modification. Zhang and coworkers recently report that zirconium modified MCM-48 could remain its cubic mesoporous structure even after calcination at $800^{\circ} \mathrm{C}$ for $4 \mathrm{~h}$ or after hydrothermal treatment in water at $100^{\circ} \mathrm{C}$ for $24 \mathrm{~h} \mathrm{[10]}$. Incorporations of rare metals such as $\mathrm{La}$ [11] and $\mathrm{Ce}$ [12] and transition metals like $\mathrm{Fe}$ [12], $\mathrm{Mn}$ [13], Ti [14], Sn [15], $\mathrm{W}$ [16], $\mathrm{V}$ [17], $\mathrm{Cu}$ [18] and $\mathrm{Zn}$ [18] etc. into the framework of the MCM-48 have been also reported. These incorporated metal ions may serve as active sites or structural stabilizers of the MCM-48 solid.

The surface acidity of mesoporous materials can be effectively enhanced through multifunctionalization approach. It is reported that by grafting some strong acid sites like sulfate ions [19] or heteropolyacids [20,21], onto the surface of mesoporous materials MCM-41, its 
surface Brønsted acidity can be generated and the total number of acid sites is significantly increased. Salas et al. once reported the modification of thermal stability and surface acidity of MCM-41 by using surface sulfating and zirconium substitution in the framework [22]. However, their results show that the surface acidity enhancement seems not significant. Late on, Wang and coworkers simultaneously introduced $\mathrm{Zr}^{4+}$ ions into the framework and grafted heteropoly acid on the surface of MCM41 , both thermal stability and surface acidity were improved [23]. Unfortunately, investigation on surface acidity of the mesoporous materials was tensely concentrated on the MCM-41. Up to date, little attention was paid on the surface acidic property of pure or modified MCM-48 [16]. Owing to the importance of the acidity of MCM-48 material in the acid catalyzed reactions, studies on the enhancement of surface acidity of MCM-48 will be of interesting.

In the present work, we describe an approach for double modifications of Si-based MCM-48 by framework substitution by $\mathrm{Zr}$ ions and surface grafting with 12-phosphotungstic acid. Introducing zirconium ions into the framework of MCM-48 aims to enhancing its hydrothermal stability, while surface grafting with heteropoly acid is for creating acid sites in Zr-MCM-48 for acidic catalysis reactions. Because the hydrothermal stability of the Zr-MCM-48 has been studied by other researchers [10], herein we will mainly focus our attention on the Keggin structure and surface acidity properties of $\mathrm{H}_{3} \mathrm{PW}_{12} \mathrm{O}_{40} / \mathrm{Zr}-\mathrm{MCM}-48$ materials.

\section{Experimental}

\subsection{Synthesis of Zr-MCM-48 and $\mathrm{H}_{3} \mathrm{PW}_{12} \mathrm{O}_{40} / \mathrm{Zr}-\mathrm{MCM}-48$}

A Zr-incorporated MCM-48 mesoporous molecular sieves was synthesized through a surfactant-templated method using tetraethyl orthosilicate (TEOS) as Si precursor and zirconyl chloride octahydrate $(>99 \%)$ as $\mathrm{Zr}$ source, along with cetyltrimethylammonium chloride $(\mathrm{CTACl})$ (25 $\mathrm{wt} \%$ solution in water) as synthesis template. The molar composition of the starting materials was controlled as:

\section{TEOS:0.1ZrOCl $2: 0.75 \mathrm{CTACl}: 0.5 \mathrm{NaOH}: 120 \mathrm{H}_{2} \mathrm{O}$.}

According to this composition, a given amount of $\mathrm{CATCl}$ surfactant, $\mathrm{NaOH}$ and water was mixed at $50^{\circ} \mathrm{C}$ with magnetic stirring for $0.5 \mathrm{~h}$. Then TEOS and zirconyl chloride octahydrate were slowly added into the above solution with vigorous agitation for $2 \mathrm{~h}$. The product was aged at $110^{\circ} \mathrm{C}$ for $72 \mathrm{~h}$ in a sealed Teflon bottle under autogenous pressure. The resultant slurry, containing a white precipitate, was filtered and extensively washed 4 times with $500 \mathrm{ml}$ deionized water, then dried at ambient temperature for $12 \mathrm{~h}$. Finally, the resultant solid was calcined at $600^{\circ} \mathrm{C}$ for $6 \mathrm{~h}$ in a flowing air $(50 \mathrm{ml} / \mathrm{min})$. Care was taken in the calcination by controlling the temperature increasing rate at $1{ }^{\circ} \mathrm{C} / \mathrm{min}$ in order to avoid any collapsing of the mesoporous structure of the products due to the temperature rapid increasing.

The $30 \mathrm{wt} \% \mathrm{H}_{3} \mathrm{PW}_{12} \mathrm{O}_{40} / \mathrm{Zr}-\mathrm{MCM}-48$ catalyst was prepared by impregnating the Zr-MCM-48 sample with a proper amount of $\mathrm{H}_{3} \mathrm{PW}_{12} \mathrm{O}_{40}$ (noted as $\mathrm{HPW}$ ) in $50 \mathrm{ml}$ methanol. The solvent was evaporated at $40^{\circ} \mathrm{C}$ in a rotary. The dried solids were calcined in air at $400^{\circ} \mathrm{C}$ in air for 2 h.

\subsection{Characterization}

The X-ray diffraction patterns of the calcined sample were measured in a D-500 SIEMENS diffractometer with a monochromatic $\mathrm{CuK} \alpha$ radiation. The scanning was made for a $2 \theta$ angle from $1.5^{\circ}$ to $10^{\circ}$, with a step size of $0.02^{\circ}$ and a step time of $2 \mathrm{~s}$. Position correction was made using the NIST standard reference material 675.

The surface area, pore volume and pore size distribution of the samples were measured with a Digisorb 2600 using $\mathrm{N}_{2}$ adsorption-desorption isotherms method. Before the measurement, the sample was treated at $300^{\circ} \mathrm{C}$ under vacuum to remove the surface impurities. The surface area was computed by using the multi-point Brunauer-Emmett-Teller (BET) method based on the adsorption data in the partial pressure $\mathrm{P} / \mathrm{P}_{\mathrm{o}}$ range from 0.01 to 0.2 . The value of $0.1620 \mathrm{~nm}^{2}$ was taken for the cross-section area of the adsorbed $\mathrm{N}_{2}$ molecule. The pore diameters were determined by using the $(\mathrm{BJH})$ method.

Solid state ${ }^{31} \mathrm{P}$ MAS-NMR spectra were recorded with a Bruker $400 \mathrm{MHz}$ spectrometer at room temperature at a frequency of $79.49 \mathrm{MHz}$, spinning of $7.5 \mathrm{kHz}$, emtting pulses at $90 \mathrm{~s}$ intervals and using $4 \mathrm{~mm}$ zirconia rotors. $85 \% \mathrm{H}_{3} \mathrm{PO}_{4}$ solution $(0 \mathrm{ppm})$ was used as reference to obtain the chemical shift. The spectral deconvolution was performed with the Unity spectrometer software.

High Resolution TEM was carried out at room temperature in a JEOL 4000 EX electron microscope equipped with a pole piece having a spherical aberration coefficient of $\mathrm{C}_{\mathrm{s}}=1.00 \mathrm{~mm}$. The powder sample was softly grounded in an agate mortar and dispersed in isopropyl alcohol within an ultrasonic bath for several minutes. A few drops were then deposited on 200 mesh copper grids covered with a carbon film. Mesostructures of the solid were imaged directly by a conventional method.

The surface acidity of the samples was analyzed by FTIR method of pyridine adsorption on a 170-SX FTIR spectrometer in a temperature range between 25 and $400^{\circ} \mathrm{C}$. Before pyridine adsorption, the sample was heated to $400^{\circ} \mathrm{C}$ under vacuum, then cooled down to room temperature. Afterwards, the solid wafer was exposed to 
pyridine by breaking, inside the spectrometer cell, a capillary containing $50 \mu \mathrm{l}$ of liquid pyridine. The FTIR spectra were recorded under various conditions by increasing the IR cell temperature from $25^{\circ} \mathrm{C}$ to $400^{\circ} \mathrm{C}$. The quantitative calculation of Lewis and Brønsted acid sites was made with respect to the area of the adsorption bands at $1450 \mathrm{~cm}^{-1}$ and $1540 \mathrm{~cm}^{-1}$, respectively [24,25]. The areas of the IR absorption bands at 1450 and 1540 $\mathrm{cm}^{-1}$ at different temperatures were integrated by using the extinction coefficients $E_{B}=1.0086 \mu \mathrm{mol} / \mathrm{cm}^{2}$ for Brønsted acid sites and $E_{L}=0.9374 \mu \mathrm{mol} / \mathrm{cm}^{2}$ for Lewis acid sites. The acid strength was determined according to the variation of the number of acid sites as a function of the temperature.

\section{Results and Discussion}

\subsection{XRD Analysis}

The low angle XRD patterns of the calcined sample are shown in Figure 1. Several peaks at approximately $2.2^{\circ}$, $2.5^{\circ}, 3.7^{\circ}, 4.3^{\circ}$ and $4.9^{\circ}$ diffraction angles are observed, these correspond to the reflections of the (211), (220), (400), (321) and (420) planes of a typical MCM-48 mesostructure with Ia3d cubic symmetry (hereafter, denoted as $\mathrm{Zr}-\mathrm{MCM}-48)$ [1].

\subsection{Textural Properties}

The textural characteristics of $\mathrm{Zr}-\mathrm{MCM}-48$ and $\mathrm{H}_{3} \mathrm{PW}_{12} \mathrm{O}_{40} /$ Zr-MCM-48 samples were determined from nitrogen adsorption-desorption isotherms. The surface area, pore volume and average pore diameter are reported in Table 1. Zr-MCM-48 has a surface area $797.8 \mathrm{~m}^{2} / \mathrm{g}$, pore volume $0.75 \mathrm{~cm}^{3} / \mathrm{g}$ and an average pore diameter $3.8 \mathrm{~nm}$. After grafting with $30 \mathrm{wt} \% \mathrm{H}_{3} \mathrm{PW}_{12} \mathrm{O}_{40}$, the surface area diminishes to $674.1 \mathrm{~m}^{2} / \mathrm{g}$, pore volume and average pore diameter to $0.66 \mathrm{~cm}^{3} / \mathrm{g}$ and $3.2 \mathrm{~nm}$, respectively. This is due to the surface coverage and partial pore blocking by

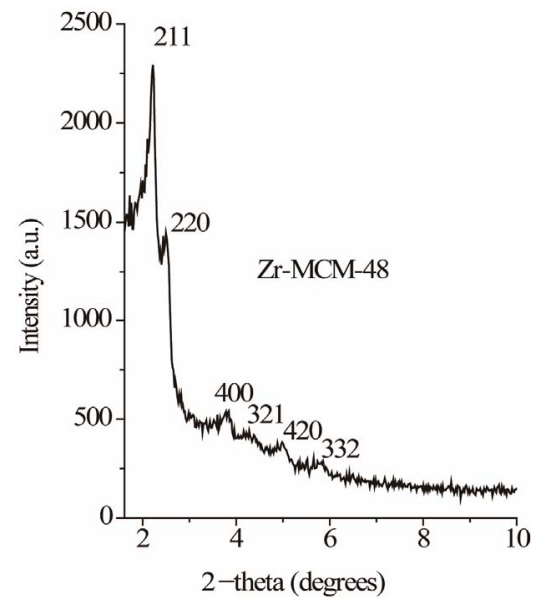

Figure 1. Low angle XRD patterns of Zr-MCM-48 solid.
Table 1. Textural data of Zr-MCM-48 and HPW/ZrMCM48 solids.

\begin{tabular}{ccc}
\hline & Zr-MCM-48 & HPW/Zr-MCM-48 \\
\hline Surface area $\left(\mathrm{m}^{2} / \mathrm{g}\right)$ & 797.8 & 674.1 \\
Pore diameter $(\mathrm{nm})$ & 3.8 & 3.2 \\
Pore volume $\left(\mathrm{cm}^{3} / \mathrm{g}\right)$ & 0.75 & 0.66 \\
\hline
\end{tabular}

the deposited heteropolyacid which was confirmed by high resolution TEM observation shown in the following section.

\subsection{High-Resolution TEM Observation}

Figure 2 shows the morphologies of the $\mathrm{Zr}-\mathrm{MCM}-48$ and $\mathrm{H}_{3} \mathrm{PW}_{12} \mathrm{O}_{40} / \mathrm{Zr}-\mathrm{MCM}-48$ solids observed by high resolution TEM. The Zr-MCM-48, Figure 2(A), shows a very ordered pore system with pore diameter between 2.5 and $4 \mathrm{~nm}$. In some areas, surface structural defects are observed. The structural imprefects may be formed in the calcination procedure due to collapse of the walls between adjact pores resulted from the removal or combustion of the synthetic template, herein the surfactant.

Figure 2(B) shows high resolution TEM image of the $\mathrm{H}_{3} \mathrm{PW}_{12} \mathrm{O}_{40} / \mathrm{Zr}-\mathrm{MCM}-48$ sample. Most of the regions are covered with nanoparticles with diameter $2-3 \mathrm{~nm}$, indicating a high dispersion of the supported heteropolyacid clusters. The diameter of a single $\mathrm{H}_{3} \mathrm{PW}_{12} \mathrm{O}_{40}$ molecule is estimated to be $1-1.2 \mathrm{~nm}$, which is smaller than the dimension of the pores $(2.5-4 \mathrm{~nm})$. Therefore, the heteropolyacid species can locate inside the internal pore of the support. However, it is also possible that the $\mathrm{H}_{3} \mathrm{PW}_{12} \mathrm{O}_{40}$ molecules forms clusters by assembling several molecules, leading to most of particles having diameter $2-3 \mathrm{~nm}$, and some of these larger than the dimension of the pores. Therefore, heteropolyacid may locate inside the internal pores, or disperse on the external surface of the support. These TEM image reveals that heteropolyacids dispersion is very homogeneous and large heteropolyacid aggregates with diameter larger than $6 \mathrm{~nm}$ are not formed in the $\mathrm{H}_{3} \mathrm{PW}_{12} \mathrm{O}_{40} / \mathrm{Zr}-\mathrm{MCM}-48$ sample.

\subsection{Keggin Structure Stability of the $\mathrm{H}_{3} \mathrm{PW}_{12} \mathrm{O}_{40} / \mathrm{Zr}-\mathrm{MCM}-48$}

In the $\mathrm{H}_{3} \mathrm{PW}_{12} \mathrm{O}_{40} / \mathrm{Zr}$-MCM-48 solid, the dispersion and structural stability of Keggin unit in the $\mathrm{H}_{3} \mathrm{PW}_{12} \mathrm{O}_{40}$ are very important because they determine the surface acidity and thermal stability of the solid. In this work, two spectroscopic techniques, FTIR and ${ }^{31} \mathrm{P}$ MAS-NMR, were applied to characterize the dispersion and structural stability of Keggin structurre in the grafted $\mathrm{H}_{3} \mathrm{PW}_{12} \mathrm{O}_{40}$. Figure 3 shows the FTIR spectrum of the $\mathrm{H}_{3} \mathrm{PW}_{12} \mathrm{O}_{40} /$ Zr-MCM-48. Four bands around 1080, 982, 896 and 819 

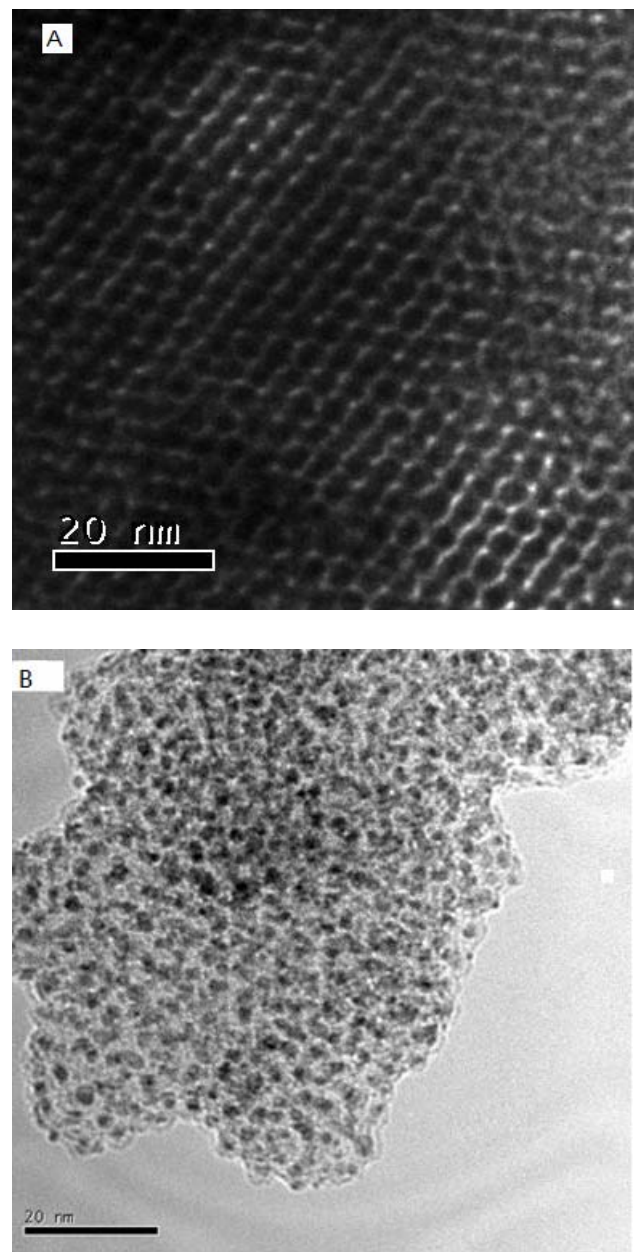

Figure 2. High Resolution TEM micrographs (A): ZrMCM-48; (B): $\mathrm{H}_{3} \mathrm{PW}_{12} \mathrm{O}_{40} / \mathrm{Zr}-\mathrm{MCM}-48$ solid.

$\mathrm{cm}^{-1}$ are observed; these bands correspond to the IR absorption vibrations of the heteropolyanions and they are very similar to the fingerprint absorption bands observed in the pure $\mathrm{H}_{3} \mathrm{PW}_{12} \mathrm{O}_{40}$ [26,27]. In the Keggin unit, the $\mathrm{P}-\mathrm{O}$ symmetric stretching is characterized by the vibrational transition at $1080 \mathrm{~cm}^{-1}$. The normal $\mathrm{W}=\mathrm{O}_{\mathrm{d}}$ stretching mode is indicated by IR band at $982 \mathrm{~cm}^{-1}$. The bands at 896 and $819 \mathrm{~cm}^{-1}$ are associated with the stretching motion of $\mathrm{W}-\mathrm{O}-\mathrm{W}$ bridges. The band at 896 $\mathrm{cm}^{-1}$ is assigned to the $\mathrm{W}-\mathrm{O}_{\mathrm{b}}-\mathrm{W}$ stretching mode (interbridges between corner sharing octahedral) and the band at $819 \mathrm{~cm}^{-1}$ is attributed to $\mathrm{W}-\mathrm{O}_{\mathrm{c}}-\mathrm{W}$ stretching mode (intra-bridges between edge sharing octahedral) [26,27]. Appearance of these fingerprints of IR absorption bands indicates that the primary structure of Keggin unit in the $\mathrm{H}_{3} \mathrm{PW}_{12} \mathrm{O}_{40}$ is completely retained in the $\mathrm{H}_{3} \mathrm{PW}_{12} \mathrm{O}_{40} /$ $\mathrm{Zr}-\mathrm{MCM}-48$ solid after thermal treatment at $400^{\circ} \mathrm{C}$ for 2 h.

Figure 4 shows the spectrum of ${ }^{31} \mathrm{P}$ MAS-NMR spectroscopy of $\mathrm{H}_{3} \mathrm{PW}_{12} \mathrm{O}_{40} / \mathrm{Zr}-\mathrm{MCM}-48$ solid. One strong signal is present at approximately $-13.48 \mathrm{ppm}$. In addi- tion, two very small peaks are observed at $-14.94 \mathrm{ppm}$ and $-12.11 \mathrm{ppm}$, respectively. The ${ }^{31} \mathrm{P}$ MAS-NMR spectroscopic features of $\mathrm{H}_{3} \mathrm{PW}_{12} \mathrm{O}_{40} / \mathrm{Zr}-\mathrm{MCM}-48$ clearly differ from both the $\mathrm{H}_{3} \mathrm{PW}_{12} \mathrm{O}_{40} / \mathrm{TiO}_{2}$ [28] which shows four peaks at around $-4,-8,-11$ and $-13 \mathrm{ppm}$, and that shown in $\mathrm{A}_{3} \mathrm{PW}_{12} \mathrm{O}_{40} / \mathrm{Zr}-\mathrm{MCM}-41$ sample where three NMR peaks at approximately $-12.2,-13.5$ and -14.9 ppm were observed [29]. The resonances observed in the $\mathrm{TiO}_{2}$ and $\mathrm{Zr}-\mathrm{MCM}-41$ supported solids are assigned to different species: the peak at $-15--14$ ppm to dispersed $\mathrm{H}_{3} \mathrm{PW}_{12} \mathrm{O}_{40}$ particles with weak interaction with the support; the one around $-14--12$ ppm to the distorted Keggin structure due to moderately strong interacting with surface hydroxyl groups of the support; the one at -11 $-8 \mathrm{ppm}$ to the defective Keggin species due to the partial fragmentation of the Keggin structure caused by the strong interaction with the support and the one around -4 ppm to phosphorus species derived from a highly fragmented Keggin unit, respectively [28,29].

With respect to the pure $\mathrm{H}_{3} \mathrm{PW}_{12} \mathrm{O}_{40}$ where only a sharp

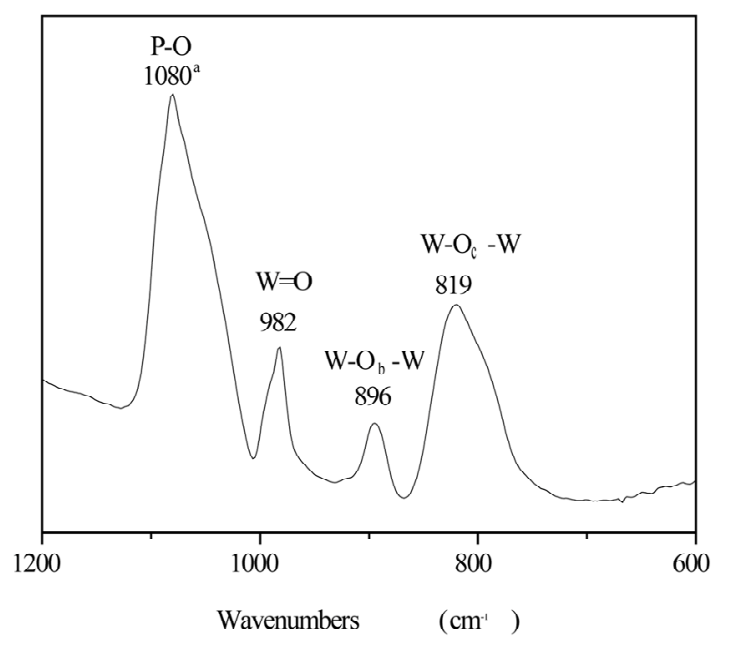

Figure 3. FTIR spectrum of the HPW/Zr-MCM-48.

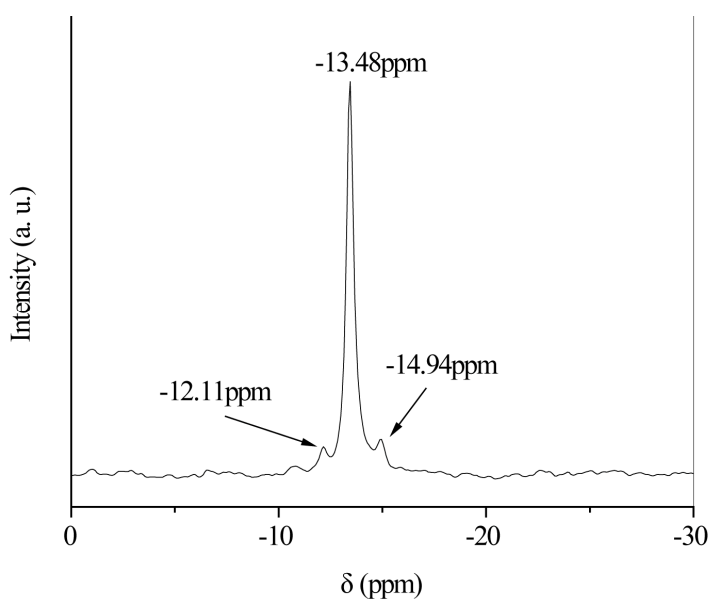

Figure 4. ${ }^{31}$ P MAS-NMR spectrum of HPW/Zr-MCM-48. 
peak appears at around -14.93 ppm, Figure 5, a peak position shift $(\Delta \delta=-1.45 \mathrm{ppm})$ is observed in the $\mathrm{H}_{3} \mathrm{PW}_{12} \mathrm{O}_{40} / \mathrm{Zr}-\mathrm{MCM}-48$ sample. The main peak position shift indicates that the Keggin structure is deformed in certain degree. Because no peaks around $-4,-8,-11$ ppm were observed in the $\mathrm{H}_{3} \mathrm{PW}_{12} \mathrm{O}_{40} / \mathrm{Zr}-\mathrm{MCM}-48$ sample, the formation of highly fragmented or a partially fragmented or defective Keggin unit can be completely excluded. The major peak at -13.48 ppm indicates that the more than $93.3 \%$ of Keggin structure in the dispersed heteropolyacid compound of $\mathrm{H}_{3} \mathrm{PW}_{12} \mathrm{O}_{4} / \mathrm{Zr}-\mathrm{MCM}-48$ were remained without destruction but slightly distorted. The weak signal at $-14.94 \mathrm{ppm}(3.6 \%)$ can be assigned to large $\mathrm{H}_{3} \mathrm{PW}_{12} \mathrm{O}_{40}$ particles similar to bulk 12phosphotungstic acid crystals having very weak interaction with MCM-48 support; while, the one at -12.11 ppm $(3.1 \%)$ is due to the formation of the species $\left(\mathrm{M}-O H_{2}^{+}\right)_{2}\left(\mathrm{HPW}_{12} \mathrm{O}_{40}^{2-}\right)$, where $\mathrm{M}$ is $\mathrm{Zr}$ or $\mathrm{Si}$ ions, by Keggin units interacting with surface hydroxyl groups, which is slightly different from the species $\left(\mathrm{M}-\mathrm{OH}^{+}\right)$ $\left(\mathrm{H}_{2} \mathrm{PW}_{12} \mathrm{O}_{40}^{-}\right)$as indicated by the NMR resonance at -13.48 ppm [29].

The results of FTIR and ${ }^{31} \mathrm{P}$ MAS-NMR characterizations confirm that the Keggin structure of $\mathrm{H}_{3} \mathrm{PW}_{12} \mathrm{O}_{40}$ is rather stable; it is only slightly deformed after impregnation and calcination at $400^{\circ} \mathrm{C}$. This conclusion is important because the Keggin structure at $400^{\circ} \mathrm{C}$ has a great influence on the surface property, i.e. surface acidity of the $\mathrm{H}_{3} \mathrm{PW}_{12} \mathrm{O}_{40} / \mathrm{Zr}-\mathrm{MCM}-48$.

\subsection{Surface Acidity}

Although the goal to introduce zirconium ion into the framework of MCM-48 is to improve the thermal and hydrothermal stability, it certainly influences the surface acidity. In order to study the surface acidity property, both $\mathrm{Zr}-\mathrm{MCM}-48$ and $\mathrm{H}_{3} \mathrm{PW}_{12} \mathrm{O}_{40} / \mathrm{Zr}-\mathrm{MCM}-48$ samples were comparatively measured by in situ FT-IR spectroscopy of pyridine adsorption. Figure 6 shows a set of in

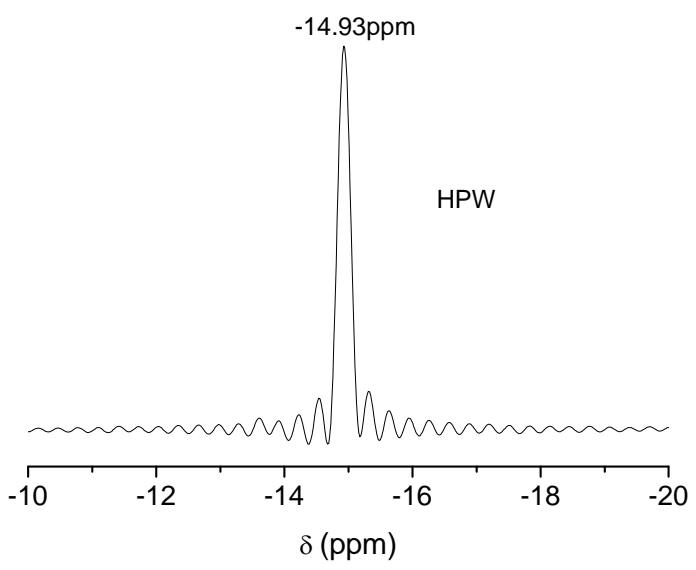

Figure 5. ${ }^{31} \mathrm{P}$ MAS-NMR spectrum of pure $\mathrm{H}_{3} \mathrm{PW}_{12} \mathrm{O}_{40}$. situ FTIR spectra of pyridine adsorption on the ZrMCM-48 support. The absorption band at $1445 \mathrm{~cm}^{-1}$ in the IR spectra corresponds to the pyridine associating with Lewis acid sites (noted as L) of the solid [30,31]. Another band at $1540 \mathrm{~cm}^{-1}$ was observed, indicating the formation of Brönsted acid sites (noted as B) in the sample [31,32]. In addition, an IR band corresponding to pyridine vibrations associated with both, Lewis and Brønsted acid sites (noted as B + L acid sites), was observed at $1490 \mathrm{~cm}^{-1}$. The band at $1640 \mathrm{~cm}^{-1}$ was assigned to pyridine adsorbed on the hydroxyls ions. As the thermal treatment temperature in the IR cell increased from $50^{\circ} \mathrm{C}$ to $100^{\circ} \mathrm{C}$ under vacuum condition, the intensities of all the bands significantly lowered. After calcination at $200^{\circ} \mathrm{C}$, these bands were further reduced and finally they completely disappeared at $250^{\circ} \mathrm{C}$.

Due to the neutral framework of pure Si-based MCM48 , it does not contain any Brønsted acid sites; therefore, the formaton of the Brønsted acid sites in the $\mathrm{Zr}$ substituted MCM-48 should relate to the replacement of $\mathrm{Si}^{4+}$ by $\mathrm{Zr}^{4+}$ ions in the framework of the MCM-48. It is noted that $\mathrm{Zr}^{4+}$ ion $(\mathrm{r}=0.084 \mathrm{~nm})$ has diameter three times greater than that of $\mathrm{Si}^{4+}$ ion $(\mathrm{r}=0.026 \mathrm{~nm})$, thus the bond length of $\mathrm{Zr}-\mathrm{O}(0.21 \mathrm{~nm})$ is longer than that of Si-O bond $(0.16 \mathrm{~nm})$. When the smaller $\mathrm{Si}^{4+}$ ions are substituted by the larger $\mathrm{Zr}^{4+}$ ions in the lattice cell of the solid framework, the formed $\mathrm{Zr}-\mathrm{O}-\mathrm{Si}$ bond length is clearly different from the one of $\mathrm{Si}-\mathrm{O}-\mathrm{Si}$, and this must generate structural microstrain within the lattice cell. Any change in the electron density around $\mathrm{Si}$ nuclei, due to either charge unbalance, or difference in electronegativity or local structure deformation resulting from the introduction of the $\mathrm{Zr}^{4+}$ ion into the vicinity of the hydroxyls carrying silicon, may weaken the $\mathrm{SiOZr-O}-\mathrm{H}$ bond [33], giving rise to the formation of Brønsted acid sites in Zr-MCM-48.

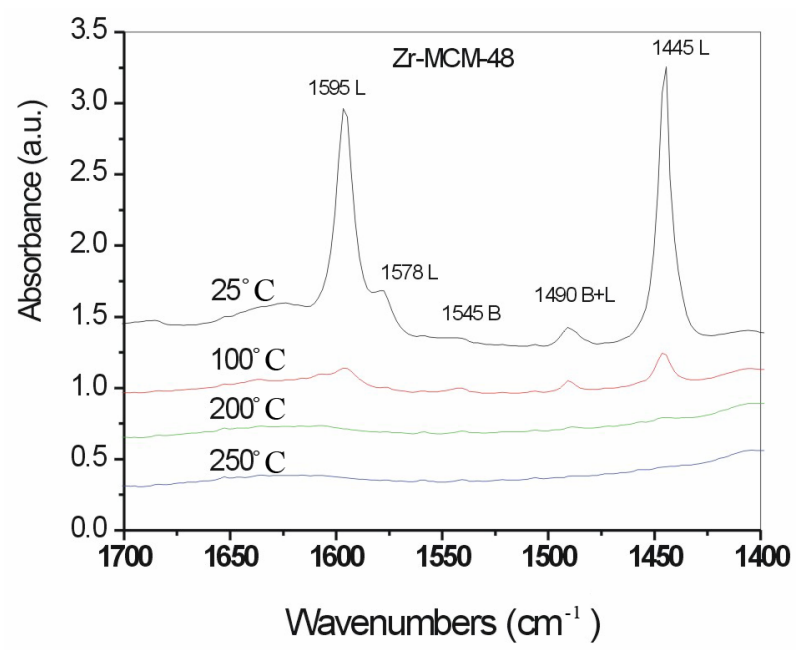

Figure 6. A set of FTIR spectra of pyridine adsorption-desorption of Zr-MCM-48 sample at different temperatures. 


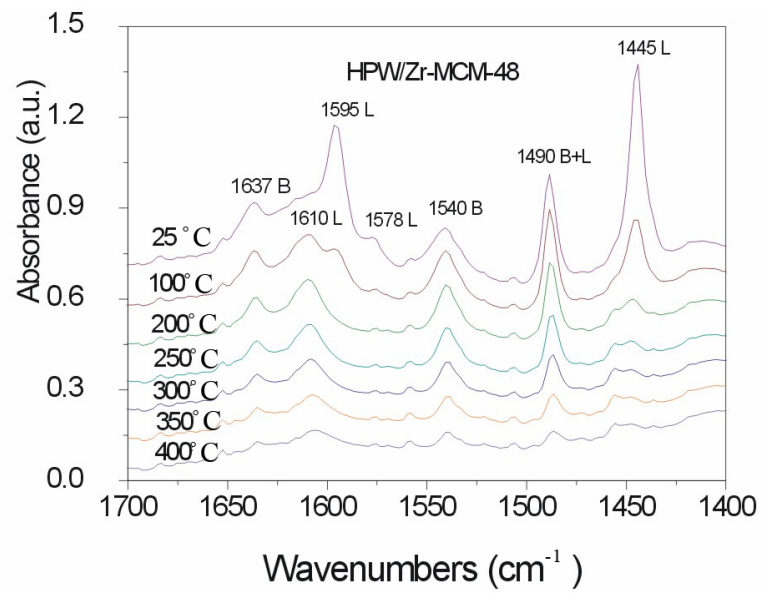

Figure 7. A set of FTIR spectra of pyridine adsorption-desorption of $\mathrm{H}_{3} \mathrm{PW}_{12} \mathrm{O}_{40} / \mathrm{Zr}-\mathrm{MCM}-48$ at differrent temperatures.

As shown in Figure 6, the Brønsted acidity of the $\mathrm{Zr}-\mathrm{MCM}-48$ is not sufficient and the acidity strength is still week, enhancement of both the number and strength of the Brønsted acid sites becomes necessary if $\mathrm{Zr}$ MCM-48 is considered as catalyst for acid catalyzed reactions like n-alkanes hydroisomerization.

The FTIR spectra of pyridine adsorption on the $\mathrm{H}_{3} \mathrm{PW}_{12} \mathrm{O}_{40} / \mathrm{Zr}$-MCM-48 catalyst are shown in Figure 7. The quantitative acidity data derived from the FTIR spectra of Figures $\mathbf{6}$ and $\mathbf{7}$ are reported in Tables $\mathbf{2}$ and 3, respectively. Both Brønsted (B) and Lewis (L) acid sites coexisted on the solid as indicated by the adsorption bands at $1450 \mathrm{~cm}^{-1}$ (L), $1610 \mathrm{~cm}^{-1}$ (L), $1540 \mathrm{~cm}^{-1}$ (B) and $1637 \mathrm{~cm}^{-1}$ (B). The bands at 1595 and $1578 \mathrm{~cm}^{-1}$ are assigned to the hydrogen-bonded pyridine and they were very weak and rapidly disappeared after thermal treatment at $200^{\circ} \mathrm{C}$ [30]. In comparison with the bare $\mathrm{Zr}$ MCM-48 support, the number of the Brønsted acid sites of the heteropolyacid grafted $\mathrm{H}_{3} \mathrm{PW}_{12} \mathrm{O}_{40} / \mathrm{Zr}-\mathrm{MCM}-48$ catalyst was greatly enhanced by 21.7 times at $100^{\circ} \mathrm{C}$ (Tables 2 and 3). Also, the acidity strength was significantly improved as evidenced by the acid nature even after $400^{\circ} \mathrm{C}$ of treatment, $36 \mu \mathrm{mol} / \mathrm{g}$ B sites and 28 $\mu \mathrm{mol} / \mathrm{g} \mathrm{L}$ sites still remain in the $\mathrm{H}_{3} \mathrm{PW}_{12} \mathrm{O}_{40} / \mathrm{Zr}-\mathrm{MCM}$ 48.

The Brønsted acidity strength is closely correlate with the Keggin sturcture and the dispersion of the loaded heteropoly anions which are determined by the interacttion between heteropoly acid and the support. The strong acidity of the $\mathrm{H}_{3} \mathrm{PW}_{12} \mathrm{O}_{40} / \mathrm{Zr}-\mathrm{MCM}-48$ may relate to the three dimensional pore system of the Zr-MCM-48 support. These hydroxyls may have a moderately strong interaction with the heteropolyacid, producing a big number of Brønsted acid sites. This $\mathrm{H}_{3} \mathrm{PW}_{12} \mathrm{O}_{40} / \mathrm{Zr}-\mathrm{MCM}-48$ solid with three dimensional mesoporous system, large surface area and very strong Brønsted acidity will be a
Table 2. Acid sites on Zr-MCM-48 solid at different temperatures.

\begin{tabular}{cccc}
\hline Temperature $\left({ }^{\circ} \mathrm{C}\right)$ & $\mathrm{B}(\mu \mathrm{mol} / \mathrm{g})$ & $\mathrm{L}(\mu \mathrm{mol} / \mathrm{g})$ & Total $(\mu \mathrm{mol} / \mathrm{g})$ \\
\hline 25 & 14 & 968 & 982 \\
100 & 8 & 94 & 106 \\
200 & 0 & 7 & 7 \\
250 & 0 & 0 & 0 \\
\hline
\end{tabular}

Table 3. Acid sites on HPW/Zr-MCM-48 solid at different temperatures.

\begin{tabular}{cccc}
\hline Temperature $\left({ }^{\circ} \mathrm{C}\right)$ & $\mathrm{B}(\mu \mathrm{mol} / \mathrm{g})$ & $\mathrm{L}(\mu \mathrm{mol} / \mathrm{g})$ & Total $(\mu \mathrm{mol} / \mathrm{g})$ \\
\hline 100 & 174 & 164 & 338 \\
200 & 142 & 56 & 198 \\
250 & 118 & 52 & 170 \\
300 & 91 & 39 & 130 \\
350 & 59 & 36 & 95 \\
400 & 36 & 28 & 6 \\
\hline
\end{tabular}

promising catalyst for acid catalytic reactions. The catalytic evaluation will be carried out in the near future.

\section{Conclusion}

Incorporation of zirconium ions into the framework of the mesoporous silica generates Brønsted acidity which would be remarkably enhanced by more than 21.7 times after surface grafting with $30 \mathrm{wt} \%$ 12-tungstophosphoric acid. The highly dispersed heteropolyacid was uniformly distributed within the pores or pore openings of $\mathrm{Zr}-\mathrm{MM}-48$ solid, and after thermal treatment at $400^{\circ} \mathrm{C}$ for $2 \mathrm{~h}$, the Keggin structure in the heteropoly anions of the $\mathrm{H}_{3} \mathrm{PW}_{12} \mathrm{O}_{40} / \mathrm{Zr}-\mathrm{MCM}-48$ was only deformed in some degree without destruction as evidenced by FTIR, TEM and ${ }^{31} \mathrm{P}$ MAS-NMR characterizations.

\section{Acknowledgements}

The authors thank Dr. P. Pérez Romo and Dr. A. Paz for their help in the NMR and TEM characterization.

\section{REFERENCES}

[1] J. S. Beck, J. C. Vartuli, W. J. Roth, M. E. Leonowics, C. T. Kresge, K. D. Schmitt, C. T.-W. Chu, D. H. Olson, E. W. Sheppard, S. B. McCullen, J. B. Higgins and J. L. Schlenker, "A New Family of Mesoporous Molecular Sieves Prepared with Liquid Crystal Templates," Journal of the American Chemistry Society, Vol. 114, No. 27, 1992, pp. 10834-10843. doi:10.1021/ja00053a020

[2] A. Corma, "From Microporous to Mesoporous Molecular 
Sieve Materials and Their Use in Catalysis," Chemical Reviews, Vol. 97, No. 6, 1997, pp. 2373-2420. doi:10.1021/cr960406n

[3] K. M. Reddy and C. Song, "From Microporous to Mesoporous Molecular Sieve Materials and Their Use in Catalysis," Catalysis Today, Vol. 31, No. 1-2, 1996, pp. 137-144. doi:10.1016/0920-5861(96)00030-2

[4] P. Serrano, J. Aguado and J. M. Escola, "Catalytic Cracking of a Polyolefin Mixture over Different Acid Solid Catalysts," Industrial \& Engineering Chemistry Research, Vol. 39, No. 5, 2000, pp. 1177-1184. doi:10.1021/ie9906363

[5] A. Ghanbari-Siahkali, A. Philippou, J. Dwyer and M. W. Anderson, "The Acidity and Catalytic Activity of Heteropoly Acid on MCM-41 Investigated by MAS NMR, FTIR and Catalytic Tests," Applied Catalysis A: General, Vol. 192, No. 1, 2000, pp. 57-69. doi:10.1016/S0926-860X(99)00333-6

[6] Y. Zhao, S. L. Qiu, Y. Tang and C. Z. Yu, "Recent Progress in Mesostuctured Materials," Studies in Surface Science and Catalysis ,Vol. 165, No. 65, 2007, pp. 1-920.

[7] V. Alfredsson and M. W. Anderson, "Structure of MCM48 Revealed by Transmission Electron Microscopy," Chemistry of Materials, Vol. 8, No. 5, 1996, pp. 11411146. doi: $10.1021 / \mathrm{cm} 950568 \mathrm{k}$

[8] T. J. V. Yates, J. M. Thomas, J.-J. Fernandez, O. Terasaki, R. Ryoo and P. A. Midgley, "Three-Dimensional RealSpace Crystallography of MCM-48 Mesoporous Silica Revealed by Scanning Transmission Electron Tomography," Chemical Physics Letters, Vol. 418, No. 4-6, 2006 , pp. 540-543.

[9] J. M. Kim and R. Ryoo, "Synthesis of MCM-48 Single Crystals," Chemical Communications, Vol. 7, No. 2, 1998, pp. 259-560.

[10] T. S. Jiang, D. L. Wu, J. N. Song, X. P. Zhou, Q. Zhao, M. R. Ji and H. B. Yin, "Synthesis and Characterization of Zr-MCM-48 with Good Thermal and Hydrothermal Stability," Powder Technology, Vol. 207, No. 1-3, 2011, pp. 422-427. doi:10.1016/j.powtec.2010.11.030

[11] W. C. Zhan, Y. L. Guo, Y. Q. Wang, X. H. Liu, Y. Guo, Y. S. Wang, Z. G. Zhang and G. Z. Lu, Synthesis of Lanthanum-Doped MCM-48 Molecular Sieves and Its Catalytic Performance for the Oxidation of Styrene," The Journal of Physical Chemistry B, Vol. 111, No. 42, 2007, pp. 12103-12110. doi:10.1021/jp0745211

[12] Y. F. Shao, L. Z. Wang, J. L. Zhang and M. Anpo, "Synthesis of Hydrothermally Stable and Long-Range Ordered Ce-MCM-48 and Fe-MCM-48 Materials," The Journal of Physical Chemistry B, Vol. 109, No. 44, 2005, pp. 20835-20841. doi:10.1021/jp054024+

[13] S. Gómez, O. Giraldo, L. J. Garcés, J. Villegas and S. L. Suib, "New Synthetic Route for the Incorporation of Manganese Species into the Pores of MCM-48," Chemistry of Materials, Vol. 16, No. 12, 2004, pp. 2411-2417.

[14] S. Yuan, L. Y. Shi, K. Mori and H. Yamashita, "Synthesis of Ti-Containing MCM-48 by Using $\mathrm{TiF}_{4}$ as Titanium Source," Materials Letters, Vol. 62, No. 17-18, 2008, pp. 3028-3030. doi:10.1016/j.matlet.2008.01.100
[15] U. S. Taralkar, P. Kalita, R. Kumar and P. N. Joshi, "Synthesis, Characterization and Catalytic Performance of Sn-MCM-48 in Solvent-Free Mukaiyama-Type Aldol Condensation Reactions," Applied Catalysis A: General, Vol. 358, No. 1, 2009, pp. 88-94. doi:10.1016/j.apcata.2009.02.001

[16] X. L. Yang, W. L. Dai, R. H. Gao, H. Chen, H. X. Li, Y. Cao, K. N. Fan, "Synthesis, Characterization and Catalytic Application of Mesoporous W-MCM-48 for the Selective Oxidation of Cyclopentene to Glutaraldehyde," Journal of Molecular Catalysis A: Chemical, Vol. 241, No. 1-2, 2005, pp. 205-214. doi:10.1016/j.molcata.2005.07.025

[17] M. L. Peña, A. Dejoz, V. Fornés, F. Rey, M. I. Vázquez and J. M. López Nieto, "V-Containing MCM-41 and MCM-48 Catalysts for the Selective Oxidation of Propane in Gas Phase," Applied Catalysis A: General, Vol. 209, No. 1-2, 2001, pp. 155-164. doi:10.1016/S0926-860X(00)00761-4

[18] M. Hartmann, S. Racouchot, C. Bischof, M. Hartmann, S. Racouchot and C. Bischof, "Characterization of Copper and Zinc Containing MCM-41 and MCM-48 Mesoporous Molecular Sieves by Temperature Programmed Reduction and Carbon Monoxide Adsorption," Microporous and Mesoporous Materials, Vol. 27, No. 2-3, 1999, pp. 309320. doi:10.1016/S1387-1811(98)00264-9

[19] M. L. Guzmán-Castillo, H. Armendáriz-Herrera, A. Tobón-Cervantes, D. R. Acosta, P. Salas-Castillo, A. Montoya de la Funte and A. Vázquez-Rodriguez, "The Effect of Sulfate Ion on the Synthesis and Stability of Mesoporous Materials," Studies in Surface Science and Catalysis, Vol. 142, 2002, pp. 1039-1046. doi:10.1016/S0167-2991(02)80261-0

[20] C.-L. Chen, H.-P. Lin, S.-T. Wong and C.-Y. Mou, "Sulfated Zirconia Catalyst Supported on MCM-41 Mesoporous Molecular Sieve," Applied Catalysis A: General, Vol. 215, No. 1-2, 2001, pp. 21-30. doi:10.1016/S0926-860X(01)00504-X

[21] S. Choi, Y. Wang, Z. Nie, J. Liu and C. H. F. Peden, "Cs-Substituted Tungstophosphoric Acid Salt Supported on Mesoporous Silica," Catalysis Today, Vol. 55, No. 1-2, 2000, pp. 117-124. doi:10.1016/S0920-5861(99)00231-X

[22] P. Salas, L. F. Chen, J. A. Wang, H. Armendáriz, M. L. Guzman, J. A. Montoya and D. R. Acosta, "Thermal Stability and Surface Acidity of Mesoporous Silica Doubly Doped by Incorporation of Sulfate and Zirconium Ions," Applied Surface Science, Vol. 252, No. 4, 2005, pp. 1124-1132. doi:10.1016/j.apsusc.2005.02.032

[23] J. A. Wang, L. F. Chen, L. E. Noreña, J. Navarrete, M. E. Llanos, J. L. Contreras and O. Novaro, "Mesoporous Structure, Surface Acidity and Catalytic Properties of the Pt/Zr-MCM-41 Catalysts Promoted by 12-Tungstophosphoric Acid," Microporous and Mesoporous Materials, Vol. 112, No. 1-3, 2008, pp. 61-76. doi:10.1016/j.micromeso.2007.09.015

[24] C. A. Emeis, "Determination of Integrated Molar Extinction Coefficients for Infrared Absorption Bands of Pyridine Adsorbed on Solid Acid Catalysts," Journal of Catalysis, Vol. 141, No. 2, 1993, pp. 347-354. doi:10.1006/jcat.1993.1145

[25] T. Barzzetti, E. Selli, D. Moscotti and L. Forni, "Pyridine 
and Ammonia as Probes for FTIR Analysis of Solid Acid Catalysts," Journal of the Chemical Society, Faraday Transactions, Vol. 92, No. 8, 1996, pp. 1401-1407. doi:10.1039/ft9969201401

[26] A. V. Ivanov, T. V. Vasina, V. D. Nissenbaum, L. M. Kustov, M. N. Timofeeva and J. I. Houzvicka, "Isomerization of $n$-Hexane on the Pt-Promoted Keggin and Dawson Tungstophosphoric Heteropoly Acids Supported on Zirconia," Applied Catalysis A: General, Vol. 259, No. 1, 2004, pp. 65-72. doi:10.1016/j.apcata.2003.09.011

[27] L. R. Pizzio, C. V. Cáceres and M. N. Blanco, "Acid Catalysts Prepared by Impregnation of Tungstophosphoric Acid Solutions on Different Supports, Applied Catalysis A: General, Vol. 167, No. 2, 1998, pp. 283-294. doi:10.1016/S0926-860X(97)00328-1

[28] J. C. Edwards, C. Y. Thiel, B. Nenac and J. F. Knifton, "Solid-State NMR and FT-IR Investigation of 12-Tungstophosphoric Acid on $\mathrm{TiO}_{2}$," Catalysis Letters, Vol. 51, No. 1-2, 1998, pp. 77-83. doi:10.1023/A:1019045319788

[29] L. F. Chen, J. A. Wang, L. E. Noren, J. Aguilar, J. Navarrete, P. Salas, J. A. Montoya and P. Del Angel, "Synthesis and Physicochemical Properties of Zr-MCM41 Mesoporous Molecular Sieves and $\mathrm{Pt} / \mathrm{H}_{3} \mathrm{PW}_{12} \mathrm{O}_{40} /$
Zr-MCM-41 Catalysts," Journal of Solid State Chemistry, Vol. 180, No. 10, 2007, pp. 2958-2972.

[30] D. Srinivas, R. Srivastava and P. Ratnasamy, "Transesterifications over Titanosilicate Molecular Sieves," Catalysis Today, Vol. 96, No. 3, 2004, pp. 127-133.

[31] A. Sakthivel, S. E. Dapurkar, N. M. Gupta, S. K. Kulshreshtha and P. Selvam, "The Influence of Aluminium Sources on the Acidic Behaviour as Well as on the Catalytic Activity of Mesoporous H-AlMCM-41 Molecular Sieves," Microporous and Mesoporous Materials, Vol. 65, No. 2-3, 2003, pp. 177-187. doi:10.1016/j.micromeso.2003.08.004

[32] T. López, J. Navarrete, R. Gómez, O. Novaro, F. Figueras and H. Armentáriz, "Preparation of Sol-Gel Sulfated $\mathrm{ZrO}_{2}-\mathrm{SiO}_{2}$ and Characterization of Its Surface Acidity," Applied Catalysis A: General, Vol. 125, No. 2, 1999, pp. 217-232.

[33] J. A. Anderson, C. Fergusson, I. Rodriguez-Ramos and A. Guerrero-Ruiz, "Influence of $\mathrm{Si} / \mathrm{Zr}$ Ratio on the Formation of Surface Acidity in Silica-Zirconia Aerogels," Journal of Catalysis, Vol. 192, No. 2, 2000, pp. 344-354. doi:10.1006/jicat.2000.2850 